\title{
HUBUNGAN PENGETAHUAN IBU DAN DUKUNGAN SUAMI DENGAN PEMAKAIAN KONTRASEPSI JANGKA PANJANG DI WILAYAH KERJA PUSKESMAS RUMBAI PESISIR
}

\author{
Nurlisis, Winda Anggraini \\ Prodi Magister IKM STIKes Hang Tuah Pekanbaru \\ Email: isis.webby@yahoo.com
}

\begin{abstract}
Data from health department pekanbaru city in 2012 from $12.671 \mathrm{~kb}$ active participants dikecamatan only 353 (2,78 $\%$ one who uses a method of long-term contraception.2011 puskesmas a tassel coastal having the number of 2931 pus, users of a contraceptive method of contraception long-term (mkjp as much as the 564 (19,24\% and a decline in the year 2012 from $8.390 \mathrm{~kb}$ active participants using a method of contraception long-term (mkjp) puskesmas a tassel coastal some 261 (3.11\%.This research aims to understand the relation of knowledge mother and husband to support the use of contraceptives long-term work in the region coastal puskesmas tahun2014 a tassel.The type of research is analytic quantitative with the design case control study, conducted from the moon maret-april 2014 with a large sample 50 cases of control and 50. Of all join the who was working diwilyah puskesmas a tassel coastal 2014 which consisted of 261 people. The sample collection technique done simple random sampling.Data processed use a computer program. Using bivariate analysis by this chi squere. The result showed that of the second variables knowledge and support husband has links that are meaningful to discharging long period contraceptives in the work area coastal puskesmas a tassel year 2014 with knowledge $p$ value $=0.02$ and support husband value $=p .0,001$. Recommended to improve health information particularly about the effectiveness and efficiency of a method of contraception long-term (MKJP).
\end{abstract}

Keywords: knowledge, support the husband, MKJP

\section{PENDAHULUAN}

Kontrasepsi berasal dari kata kontra yang berarti menghindari atau mencegah terjadinya kehamilan seagai akibat pertemuan antara sel telur dengan sel sperma. Lama efektivitasnya, kontrasepsi dapat dibagi menjadi metode kontrasepsi jangka panjang (MKJP) dan metode non kontrasepsi jangka panjang (Non MKJP) yang termasuk dalam kategori jangka panjang adalah jenis Implant, AKDR, MOP dan MOW sedangkan untuk metode Non MJKP adalah kondom, pil, suntik, dan metode-metode lain selain metode yang termasuk MKJP. Metode kontrasepsi jangka panjang adaah cara kontrasepsi berjangka panjang yang dalam penggunaanya mempunyai efektivitas dan tingkat kelangsungan pemakaiannya yang tinggi dengan angka kegagalan yang rendah (BKKBN, 2009).

Pemakaian MKJP memiliki banyak keuntungan, baik dilihat dari segi program, maupun dari sisi klien (pemakai), penggunaan kontrasepsi MKJP juga lebih efisien karena dapat dipakai dalam waktu yang lama serta lebih aman dan efektif. Metode kontrasepsi ini sangat tepat digunakan pada kondisi krisis yang dialami oleh sebagian besar masyarakat Indonesia terutama pada masyarakat yang tergolong kurang mampu/miskin. Dalam situasi ini, kelompok masyarakat miskin merupakan fokus garapan pemerintah yang dianggap sangat strategis. Dilihat angka kegagalan MKJP relatif lebih rendah dibanding non-MKJP salah satunya kontrasepsi suntik sebesar (31,9\%). Angka kegagalan MKJP dilaporkan sebesar 0-2 per1000 pengguna, sedangkan metoda nonMKJP dilaporkan terjadi lebih dari 10 per 1000 pengguna (Asih L, 2009).

Hasil Survei Demografi dan Kesehatan Indonesia(SDKI) pada tahun 2011 pola penggunaan kontrasepsi di Indonesia masih didominasi oleh kontrasepsi hormonal dan bersifat jangka pendek sebesar 67,50\%, sedangkan untuk pemakaian Metode Kontrasepsi Jangka Panjang (MKJP) sebesar $12,67 \%$ dengan proporsi pemakaian AKDR 5,78\%, Implant 4,93\%, MOW 2,19\% dan MOP 0,27 . Sedangkan data SDKI 2012 pemakaian 
Metode Kontrasepsi Jangka Panjang (MKJP) mengalami penurunan menjadi $10,6 \%$. Data dari Riau 2012 memperlihatkan pemakian kontrasepsi sebanyak $54 \%$ dan yang menggunakan metode montrasepsi jangka panjang (MKJP) sebanyak 13,45\%. Dari badan kependudukan dan keluarga berencana nasional (BKKBN) menargetkan MKJP bisa mencapai $27,5 \%$ pada tahun 2014, karena dari pemerintah sudah diadakan pemasangan gratis untuk kontrasepsi AKDR dan Implant.

Berdasarkan data dari Dinas Kesehatan Kota Pekanbaru pada tahun 2012 dari 12.671 peserta KB aktif dikecamatan hanya 353 (2,78\%) orang yang menggunakan Metode Kontrasepsi Jangka Panjang. Tahun 2011 puskesmas Rumbai Pesisir memiliki jumlah PUS sebesar 2931, pengguna alat kontrasepsi Metode Kontrasepsi Jangka Panjang (MKJP) sebanyak 564 orang $(19,24 \%)$ dan terjadi penurunan ditahun 2012 dari 8.390 peserta KB aktif yang menggunakan Metode Kontrasepsi Jangka Panjang (MKJP) Puskesmas Rumbai Pesisir sebanyak 261 (3,11\%). (Dinkes Kota Pekanbaru, 2012).

Berdasarkan Survey dilapangan dari $10 \mathrm{ibu}$ yang menjadi akseptor KB aktif memberikan alasan mengapa mereka tidak menggunakan Metode Kontrasepsi Jangka Panjang (MKJP) alasannya sebagai berikut: 5 orang (50\%) kurang mengetahui tentang Metode Kontrasepsi Jangka Panjang (MKJP), 2 orang (20\%) mendengarkan keluhan dari orang lain sehingga ibu merasa takut untuk menggunakan, dan 3 orang (30\%) kurangnya dukungan suami.

Untuk menggunakan Metode Kontrasepsi Jangka Panjang (MKJP) seperti AKDR dan Implant akseptor harus mempunyai pengetahuan yang baik karena yang berpengetahuan kurang lebih besar pada wanita yang menggunakan KB non MKJP dibandingkan MKJP, yaitu 64\% berbanding $53 \%$ (BKKBN, 2012). Hal ini menunjukkan bahwa pengetahuan akseptor tentang KB secara umum yang di ukur dari "Tahu" tentang metode kontrasepsi masih rendah. Pengertian dari pengetahuan itu sendiri yaitu merupakan hasil dari "Tahu" dan ini terjadi setelah dilakukan pengindraan terhadap sesuatu objek tertentu. Pengetahuan atau kognitif merupakan dominan yang sangat penting untuk terbentuknya tindakan seseorang (Notoatmodjo, 2003).

Selain pengetahuan merupakan faktor yang penting dalam pemilihan kontrasepsi, akseptor harus mendapatkan kenyamanan dalam menggunakan kontrasepsi hal tersebut bisa didapatkan dari dukungan keluarga terutama suami karena suami merupakan pemegang kekuasaan dalam pengambilan keputusan apakah istri akan menggunakan kontrasepsi atau tidak, karena suami dipandang sebagai pelindung, pencari nafkah dalam rumah tangga dan membuat keputusan, tanpa adanya dukungan suami rasa nyaman tidak akan didapatkan. Pasangan suami istri harus bersamasama memilih metode kontrasepsi yang terbaik, saling kerja sama dalam pemakaian, membiayai pegeluaran kontrasepsi dan memperhatikan tanda dan bahaya. Dari hasil penelitian Nurbaiti (2013) menunjukkan bahwa $100 \%$ ibu yang tidak menggunakan AKDR karena tidak mendapatkan dukungan dari suami sedangkan $18 \%$ ibu yang menggunakan ADKR sebagai kontrasepsi mendapatkan dukungan dari suami (Lilestina S, 2011)

Berdasarkan latar belakang tersebut maka penulis tertarik melakukan penelitian dipuskesmas tersebut dengan judul "Hubungan Pengetahuan Ibu dan Dukungan Suami Dengan Pemakaian Kontrasepsi Jangka Panjang (MKJP) di Wilayah Kerja Puskesmas Rumbai Pesisir Tahun 2014”.

\section{METODOLOGI PENELITIAN}

Jenis penelitian ini adalah penelitian analitik kuantitatif dengan meggunakan desain casus control. Lokasi penelitian ini dilaksanakan di Wilayah Kerja Puskesmas Rumbai Pesisir Pekanbaru tahun 2014. Waktu Penelitian dilaksanakan pada bulan Maret - April tahun 2014. Populasi dalam penelitian adalah seluruh jumlah akseptor KB yang berkunjung di Puskesmas Rumbai Pesisir pada Tahun 2012 sebanyak 2931 orang. Sampel 100 responden 100 responden 50 kasus dan 50 kontrol. Dalam penelitian ini teknik pengambilan sample yang digunakan adalah Simple Random Sampling. 
pengumpulan data pada penelitian digunakan alat berupa kuisioner kepada responden yang dijadikan sampel penelitian. Dalam penelitian ini menggunakan data primer dan data sekunder. Data primer diperoleh dari akseptor KB yang berupa pengetahuan dan dukungan suami dan data sekunder diperoleh dari dinas kesehatan kota pekanbaru dan data dari Puskesmas Rumbai Pesisir. Pengolahan data dilakukan dengan beberapa tahap terdiri dari tahap editing, coding, tabulating, cleaning, proses. Analisa data yang digunakan Analisia Univariat dan Bivariat

\section{HASIL DAN PEMBAHASAN}

\section{A. Hasil Penelitian}

Berdasarkan sampel yang diambil sebanyak 100 responden semua akseptor KB aktif yang berada diwilayah kerja puskesmas rumbai pesisir tahun 2014 melalui pengisian kuisioner didapat hasil penelitian yang dikelompokkan menurut variabel independen (pengetahuan dan dukungan suami) dan variabel dependen (pemakaian Metode Kontrasepsi Jangka Panjang) adalah sebagai berikut.

\section{Analisis Univariat}

\section{a. Hubungan Pengetahuan Ibu dengan pemakaian Metode Kontrasepsi Jangka Panjang.}

Tabel 2

Hubungan Pengetahuan Ibu dengan Pemakaian Metode Kontrasepsi Jangka Panjang Di Wilayah Kerja Puskesmas Rumbai Pesisir Tahun 2014

\begin{tabular}{ccccccc}
\hline & \multicolumn{2}{c}{ KB } & \multirow{2}{*}{ Total } & P value & OR (95 \% CI) \\
\cline { 2 - 3 } Pengetahuan & Non MKJP & MKJP & & & \\
\cline { 2 - 4 } Rendah & $27(54 \%)$ & $39(78 \%)$ & $66(66 \%)$ & 0,02 & 0,33 \\
Tinggi & $23(46 \%)$ & $11(22 \%)$ & $34(34 \%)$ & & \\
\hline Total & $50100 \%$ & $50100 \%$ & $100100 \%$ & & \\
\hline
\end{tabular}

Berdasarkan Tabel 2 dapat dilihat hubungan antara pengetahuan dengan pemakaian MKJP dari 66 responden yang berpengetahuan rendah sebagian besar tidak memilih MKJP yaitu sebanyak 27 orang $(54 \%)$, Hasil dari analisis uji statistik didapatkan nilai $\mathrm{p}$ value $=0,02$, hal ini

\section{a. Pemakaian Metode Kontrasepsi Jangka Panjang}

\section{Tabel 1}

Distribusi Responden Berdasarkan Pemakaian Metode Kontrasepsi Jangka Panjang Di Wilayah

Kerja Puskesmas Rumbai Pesisir Tahun 2014

\begin{tabular}{cccc}
\hline $\mathbf{N}$ & Pemakaian MKJP & $\begin{array}{c}\text { Frekuen } \\
\text { si }\end{array}$ & $\begin{array}{c}\text { Persenta } \\
\text { se }\end{array}$ \\
\hline 1 & Menggunakan MKJP & 50 & 50 \\
& Tidak menggunakan & & \\
2 & MKJP & 50 & 50 \\
\hline & Total & 100 & 100 \\
\hline
\end{tabular}

Berdasarkan Tabel 1 didapatkan sebagian besar responden tidak menggunakan Metode Kontrasepsi Jangka Panjang sebanyak 50 responden $(50 \%)$ dan yang menggunakan Metode Kontrasepsi Jangka Panjang sebanyak 50 responden $(50 \%)$.

\section{Analisis Bivariat}

Hubung an Pengetahuan Ibu Dan Dukungan Suami Terhadap Pemakaian Metode Kontrasepsi Jangka Panjang Di Wilayah Kerja Puskesmas Rumbai Peisisr Tahun 2014 dapat dilihat pada tabel berikut: 


\section{b. Hubungan Dukungan Suami Dengan Pemakaian Metode Kontrasepsi Jangka Panjang}

Tabel 3

Hubungan Dukungan Suami dengan Pemakaian Metode Kontrasepsi Jangka Panjang Di Wilayah Kerja Puskesmas Rumbai Pesisir Tahun 2014

\begin{tabular}{lllll}
\hline \multicolumn{2}{c}{ KB } & Total & P value & OR $(95 \% \mathrm{CI})$ \\
\hline Non MKJP & MKJP &
\end{tabular}

Dukungan Suami

\begin{tabular}{lcr} 
Cidak Mendukung & $36(72 \%)$ & $1(2 \%)$ \\
Mendukung & $14(28 \%)$ & $49(98 \%)$ \\
\hline Total & $50100 \%$ & $50100, \%$ \\
\hline Berdasarkan tabel 7 dapat dilihat hubungan \\
antara dukungan & suami dengan pemakaian \\
MKJP dari 37 & responden yang tidak \\
mendapatkan dukungan suami sebagian besar \\
tidak memilih MKJP yaitu sebanyak 36 orang \\
(72\%) \\
Hasil dari analisis uji statistik didapatkan \\
nilai p value = 0,001, hal ini menunjukkan ada \\
hubungan yang signifikan antara suami dengan \\
pemakaian Metode Kontrasepsi Jangka Panjang \\
Di Wilayah Kerja Puskesmas Rumbai Pesisir \\
Pada Tahun 2014.
\end{tabular}

\section{Pembahasan}

Berdasarkan hasil penelitian yang dilakukan pada bulan Maret-April Tahun 2014 di wilayah kerja puskesmas rumbai pesisir, diperoleh data tentang hubungan tiap-tiap variabel dengan pemakaian Metode Kontrasepsi Jangka Panjang (MKJP) yang merupakan keadaan nyata yang diperoleh peneliti. Berdasarkan data tersebut dijadikan acuan dan tolak ukur dalam melakukan pembahasan dan sebagai hasil akhir dapat dinyatakan sebagai berikut:

\section{Hubungan Pengetahuan Ibu Dengan Pemakaian Metode Kontrasepsi Jangka Panjang Di Wilayah Kerja Puskesmas Rumbai Pesisir Tahun 2014.}

Hasil dari analisis uji statistik didapatkan nilai $\mathrm{p}$ value $=0,02$, hal ini menunjukkan ada hubungan yang signifikan antara pengetahuan responden dengan pemakaian Metode Kontrasepsi Jangka Panjang Di Wilayah Kerja Puskesmas Rumbai Peisisir Tahun 2014. Analisis keeratan hubungan dua variabel diperoleh nilai OR 0,33 (CI 95\% = 0,139 -
$37(37 \%)$
0,001
126
$5,83-1002,4)$

$63(63 \%)$

100100

0,790), artinya responden dengan pengetahuan rendah memiliki peluang 0,3 kali tidak memilih menggunakan MKJP dibandingkan responden dengan pengetahuan tinggi.

Hasil penelitian ini sejalan dengan penelitian yang dilakukan oleh Armainar (2011) dengan judul "Faktor- Faktor Yang Mempengaruhi Akseptor KB Dalam Memilih Alat Kontrasepsi Dalam Rahim Di Wilayah Kerja Puskesmas Minas Kabupaten Siak Tahun 2011/" yang menyatakan bahwa terdapatnya hubungan yang signifikan antara pengetahuan dengan pemilihan alat kontrasepsi dalam rahim dengan $\mathrm{p}$ value 0,003 .

Menurut WHO dalam kusmawati (2006) pengetahuan dapat membentuk keyakinan tertentu sehingga sesorang berprilaku sesuai dengan keyakinan tersebut. Pengetahuan atau kognitif merupakan domain yang sangat penting untuk terbentuknya tindakan seseorang.

Menurut asumsi peneliti pengetahuan seseorang berpengaruh dalam proses pengambilan keputusan untuk menerima sesuatu hal yang baru. Semakin rendah pengetahuan seseorang tentang sesuatu hal maka akan rendah pula tingkat kepercayaannya untuk menggunakannya. Tetapi adapun ibu yang berpengetahuan rendah banyak yang menggunakan MKJP hal itu dikarenakan adanya bantuan gratis dari pemerintah serta adanya bantuan dari tempat dimana mereka bekerja tanpa mereka tau lebih jelas bagaimana cara kerja serta efeknya dan alasan yang diberikan kebanyakan lebih baik menggunakan MKJP dari pada harus mengeluarkan dana setiap bulannya serta bisa membatasi jumlah anak karena 
ekonomi yang terbatas. Sedangkan ibu-ibu yang berpengetahuan tinggi banyak yang tidak menggunakan MKJP hanya karena mereka mengetahui efeknya serta cara pemasangannya padahal efek yang ditimbulkan hanya untuk penyesuaian tetapi mereka takut selain itu suami mendukung, dana tersedia tapi mereka lebih memilih menggunakan Non MKJP alasannya lebih simpel hanya minum pil dan suntik. Derekomendasikan ibu-ibu mendapatkan informasi kesehatan tentang MKJP lebih jelas dari petugas kesehatan.

\section{Hubungan Dukungan Suami Dengan}

Pemakaian Metode Kontrasepsi Jangka Panjang Di Wilayah Kerja Puskesmas Rumbai Pesisir Tahun 2014.

Ada hubungan yang signifikan antara dukungan suami dengan pemakaian Metode Kontrasepsi Jangka Panjang Di Wilayah Kerja Puskesmas Rumbai Pesisir Pada Tahun 2014. Analisis keeratan dua variabel diperoleh nilai OR 126 (CI $95 \%=15,83$ - 1002,4), artinya responden yang tidak mendapatkan dukungan suami memiliki peluang 126 kali tidak memilih menggunakan MKJP dibandingkan yang tidak mendapatkan dukungan suami.

Menurut Armainar (2011) dengan judul "Faktor- Faktor Yang Mempengaruhi Akseptor KB Dalam Memilih Alat Kontrasepsi Dalam Rahim Di Wilayah Kerja Puskesmas Minas Kabupaten Siak Tahun 2011 " yang menyatakan bahwa terdapatnya hub ungan yang bermakna antara dukungan suami dengan pemilihan alat kontrasepsi dalam rahim dengan $\mathrm{p}$ value 0,006 .

Dukungan suami terhadap istri dalam berKB merupakan partisipasi suami secara tidak langsung dalam berKB dengan menganjurkan, mendukung dan memberi kebebasan kepada istri untuk menggunakan kontrasepsi atau metode KB diawali sejak pria tersebut melakukan akad nikah dengan pasangannya, dalam merencanakan jumlah anak yang akan dimiliki sampai dengan akhir masa menopause istrinya (BKKBN, 2006).

Menurut asumsi peneliti dukungan suami terhadap istri dalam memilih alat kontrasepsi merupakan hal yang sangat penting, karena akseptor harus mendapatkan kenyamanan dalam menggunakan kontrasepsi hal tersebut bisa didapatkan dari dukungan keluarga terutama suami karena suami merupakan pemegang kekuasaan dalam pengambilan keputusan apakah istri akan menggunakan kontrasepsi atau tidak. Tidak adanya dukungan suami disebabkan karna beberapa faktor diantaranya pengetahuan yang kurang, pendidikan, kurangnya partisipasi suami dalam ber $\mathrm{KB}$, tidak mau mengantarkan istri ke tempat pelayanan, tidak ada dana yang diberikan, namun sebagian dari suami responden ada yang berpengetahuan rendah tetapi mereka ikut berpatisipasi dalam ber $\mathrm{KB}$, mendukung adanya program gratis dari pemerintah yang bermanfaat untuk mengatur jumlah anak.

\section{KESIMPULAN}

Dapat disimpulkan bahwa Ada hubungan yang signifikan antara pengetahuan dan dukungan suami responden dengan pemakaian Metode Kontrasepsi Jangka Panjang. Saran yang dapat diberikan yaitu Perlu peningkatan promosi penyuluhan secara menyeluruh di Wilayah Kerja Puskesmas Rumbai Pesisir kepada ibu-ibu tentang KB, terutama Metode Kontrasepsi Jangka Panjang yang meliputi pengertian, keuntungan, jenis, efesiensi dan efektivitas serta konseling pada Pemakai KB baru. Diharapkan peneliti selanjutnya dapat melakukan penelitian yang sama dengan menggunakan desain penelitian kualitatif menggali lebih dalam tentang variabel dukungan suami.

\section{DAFTAR PUSTAKA}

Armainar, (2011) Faktor- Faktor Yang Mempengaruhi Akseptor KB Dalam Memilih Alat Kontrasepsi Dalam Rahim Di Wilayah Kerja Puskesmas Minas Kabupaten Siak Tahun 2011)

Asih, L. (2009) Faktor-Faktor Yang Mempengaruhi Pemakaian Kontrasepsi Jangka Panjang (MKJP), Jakarta, KB dan Kesehatan Reproduksi. Diakses Tanggal 07 Januari 2014.

BKKBN, (2006) Keluarga Berencana, Kesehatan reproduksi, gender dan pembangunan kesehatan, Jakarta. 
Dyah, N. (2011) Panduan Lengkap Metode KB Terkini. Nuha Medika, Jogyakarta

Hidayat, A. A. (2012) Riset Keperawatan dan

Teknik Penulisan Ilmiah, Jakarta, Salemba Medika.

Kusumaningrum, R. (2009) Faktor-Faktor Yang Mempengaruhi Pemilihan Jenis Kontraseppsi Yang Digunakan Pada Pasangan Usia Subur, Semarang, KTI. Diakses Tanggal 25 Januari 2014.

Lilestina, S. (2011) Faktor-Faktor Yang Mempengaruhi Penggunaan MKJP Di Enam Wilayah Indonesia, Diakses tanggal 09 Januari 2014.

Maryatun, (2009) Analisis Faktor-Faktor Pada Ibu Yang Berpengaruh Terhadap Pemakaian Metode Kontrasepsi IUD Di Kabupaten Sukoharjo. Surakarta. Diakses tanggal 25 Januari 2014.

Meilani, dkk. (2010) Pelayanan Keluarga Berencana, Yogyakarta, Fitramaya.

Notoatmodjo, S. (2005) Metodologi Penelitian Kesehatan, Jakarta, Rineka Cipta

Notoatmodjo, S. (2010) Metodologi Penelitian Kesehatan, Jakarta, Rineka Cipta

Nurbaiti, (2013). Faktor- Faktor Yang Mempengaruhi Penggunaan Alat Kontrasepsi IUD. Diakses Tnggal 25 Januari 2014.

Pinem, S. (2009) Kesehatan Reproduksi dan Kontrasepsi, Jakarta, Trans Info Media

Proverawati, A. (2010) Panduan Memilih Kontrasepsi, Yogyakarta, Nuha Medika
Purba, (2009) Faktor-Faktor Yang Mempengaruhi Pemakaian Alat Kontrasepsi Pada Istri PUS Dikecamatan Rambah Samo Kabupaten Rikan Hulu Tahun 2008. Tesis. Diakses Tanggal 25 Januari 2014.

Ratnaningtyas, (2009) Hubungan Tingkat Pengetahuan Ibu Tentang Metode Kontrasepsi Dengan Pemakaian Kontrasepsi Hormonal Dan Non Hormonal Di RW III Desa Karangsari, Ngawi. Karya Tulis Ilmiah. Diakses Tanggal 25 Januari 2014.

Riyanto, A. (2011) Aplikasi Metodologi Penelitian Kesehatan, Yogyakarta, Nuha Medika

Saryono, (2010) Metodologi Penelitian Kesehatan, Yogyakarta, Mitra Mediak

Sulistyaningsih, (2011) Metodologi Penelitian Kebidanan Kuantitatif Kualitatif, Yogyakarta, Graha Ilmu

Sulistyawati, A. (2011) Pelayanan Keluarga Berencana, Jakarta, Salemba Medika

Suratun, (2008) Pelayanan Keluarga Berencana dan Pelayanan Kontrasepsi, Jakarta, Trans Info Media

Suyanto, (20090 Riset Kebidanan, Yogyakarta, Mitra Cendikia Press

Uliyah, M. (2010) Panduan Aman dan Sehat Memilih Alat KB, Yogyakarta, Bintang Pustaka Abadi. 